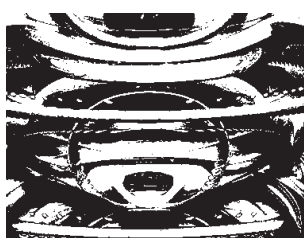

\title{
RECONCILING PARADIGMS OF PROSTITUTION THROUGH NARRATION
}

Mojca PAJNIK

Faculty of Social Sciences, Ljubliana

UDK: 176.5(497.4)

Izvorni znanstveni rad

Primljeno: 18. 6. 2012

The article focuses on the sex work / violence controversy in debates about prostitution both theoretically and empirically, with an emphasis on Central/South-Eastern Europe, and Slovenia in particular. The article first analyses studies and debates on prostitution in the region during the (post)socialist years. It then moves on to discuss the twofold effect of the liberalization of prostitution during the transition period: while, on the one hand, prostitution was destigmatized, on the other it was commodified to serve the economic interests of the emerging globalized sex and trafficking industry. Interviews with various protagonists involved in prostitution in Slovenia show how these processes affected their living and working conditions. The experiences of prostitutes reveal the complexity of their situations, showing that there is no clear-cut distinction between prostitution and trafficking and that both voluntary and involuntary elements are involved. By evaluation of arguments of both the sex work and the violence paradigms, the article proposes to study prostitution beyond binarism, in its heterogeneity, i.e. by thematizing its various aspects and by taking into consideration the realities of actors engaged in prostitution.

Keywords: prostitution, sexuality, sex work, violence, narration, Slovenia

$\triangle \quad$ Mojca Pajnik, Faculty of Social Sciences, University of Ljubliana, Kardeljeva pl. 5, 1000 Ljubljana, Slovenia. E-mail: mojca.pajnik@mirovni-institut.si

From the 1960s through to the 1980s, civil society movements, women's movements and feminist studies repeatedly prompted debate on prostitution after several decades of respite following the Second World War. This was a period when gen- 
DRUŠ. ISTRAŽ. ZAGREB GOD. 22 (2013), BR. 2, STR. 257-276

PAJNIK, M.: RECONCILING.. der inequality issues found their place in public discussion, and prostitution was first addressed as a by-product of unequal gender relations. Influential studies from this period conceptualized prostitution as sexual violence against women, similar to other types of sexual exploitation, such as pornography or sexual slavery (Barry, 1985; Dworkin, 1987). Advocacy for the abolition of prostitution soon became the target of criticism. The movements for the self-organization of prostitutes that began to emerge during the early 1970s, first in the US and Western Europe (Gall, 2006), rejected the abolitionist argumentation on the grounds of its insistence on the universalistic conception of "women's sexuality" and disregard for diversity of experience, but also objectification, passivization and victimization of women. The term "sex work" gained currency during the 1970s (Alexander, 1998; Nagle, 1997), denoting commercial sex services or performances provided in exchange for material gains, while in the decades that followed, sex work became associated with the growing global sex industry (Weitzer, 2006, 3).

The definition of prostitution as either violence or sex work continues to be the principal point of departure in both academic and policy oriented debates. Similarly polarized are polemics on human trafficking. This article focuses on the sex work / violence controversy both theoretically and empirically, with an emphasis on Central/South-Eastern Europe, and Slovenia in particular. The article first analyses debates on prostitution in the region during the (post)socialist years, which are neglected in current academic debates. It then moves on to discuss the twofold effect of the liberalization of prostitution during the transition period: while, on the one hand, prostitution was destigmatized, on the other it was commodified to serve the economic interests of the emerging globalized sex industry. The article relies on empirical work to test the predominant representation and ideologization of prostitution, while providing a closer look at the arguments behind the sex work and violence paradigms that continue to shape debates on these issues across Europe, including in Central/South-Eastern Europe. Supporters of the abolition of prostitution define trafficking in human beings as violence and argue for policies of victim protection and criminalization of perpetrators (Jeffreys, 2006; Hughes, 2000). Advocates of sex work, on the other hand, argue for the de-victimization of women involved in trafficking and draw attention to the need to deal with class divisions, social inequalities, and ethnic and gender discrimination, all of which encourage human trafficking, much more so than criminal groups (Agustín, 2005; Doezema, 2000; Kempadoo, Sanghera, \& Pattanaik, 2005). 
DRUŠ. ISTRAŽ. ZAGREB GOD. 22 (2013), BR. 2 STR. $257-276$

PAJNIK, M.: RECONCILING...
The central thesis is that the one-sided explanations of prostitution are both dubious. There is a need to move beyond the binary logic and consider the diverse character of prostitution and the many realities of women and men involved in various kinds of prostitution. The argument presented here is that the dualist understanding is inappropriate as it does not encompass the heterogeneity of experiences such as these that came to light in interviews in the Slovenian context.

This article theorizes prostitution as a form of work that may involve exploitation based on gender and class differences and discrimination on the grounds of ethnicity. Another possibility considered is that women and men involved in prostitution are not a priori victims and that a woman is not necessarily an object of sexual consumption. Taking these premises as points of departure, the article studies prostitution in its heterogeneity by thematizing its various aspects, including work, women's work, the nature of the sex industry, and last but not least, the demand.

\section{PROSTITUTION IN A POST-SOCIALIST CONTEXT}

The post-socialist countries differ greatly in their approach to gender issues. Nevertheless, the underlying similarities, which are the legacy of the socialist past and wider systemic and social changes that unfolded after 1989, justify the analysis of prostitution / trafficking within this specific framework.

The early positivist discussions that approached prostitution as a social deviation, which in a European context first emerged in England, influenced perspectives on prostitution elsewhere. Historical analyses (Radulović, 1986) show that early empirical studies from the former Yugoslavia also treated prostitution primarily as a socio-pathological phenomenon, for example Kobal's and Bavcon's study, published in 1969. During the subsequent decades, publications on the subject of prostitution were quite rare, much like elsewhere in Europe. Moreover, the vibrant women's movement across the region that created room for debate on gender inequality did not address prostitution publicly. The subject was revived in the 1990s, while the first research studies on human trafficking in Slovenia were conducted only after 2000 . The existing scholarly texts in Slovenia on prostitution and human trafficking mainly deal with its criminal and legal aspects (Kanduč, 1998; Oberstar, 2003). The argument in favour of social work approach to prostitution, one based on the normalization of the concept, was elaborated by Zaviršek (1993), while other studies discuss policy dilemmas (Hrženjak, 2008). Some texts deal with human trafficking from the standpoint of human rights (Zavratnik Zimic \& Pajnik, 2005). 
DRUŠ. ISTRAŽ. ZAGREB GOD. 22 (2013), BR. 2, STR. 257-276

PAJNIK, M.: RECONCILING...
Throughout the CEE region today, employment opportunities for women are low, particularly women over 30 . Discrimination is pronounced within the private sector, where young women mainly work under short-term contracts or engage in casual work, and the current recession seems only to have aggravated the situation. The trend that forces women to accept low-paid, insecure work within the informal sector, particularly women who do not belong to the majority ethnic group, can be observed throughout the CEE region (Corrin, 2005). It is also common for women from the CEE / SEE region to migrate to Western European countries in search of jobs, where, regardless of their qualifications, they end up performing domestic and care work. Moreover, many migrant women are left with no choice but to accept work within the sex industry (Pajnik, 2008) that has grown immensely after 1989 with a push of socialist countries from their relative isolation into the global, marketized economy (Kligman \& Limoncelli, 2005, p. 122).

Common experiences with transitions brought a shared general framework of regularization of prostitution and trafficking. Trafficking (forced prostitution) is prohibited across Europe and CEE / SEE countries are no exception. Despite some differences, the majority of countries in the region regulate prostitution with laws on offences against public order. Slovenia decriminalized prostitution while some other countries (Croatia, BiH, Serbia, Bulgaria) still persecute it while all favour prevention-like legal orientation, framing prostitution as a matter of public order. Penal codes in the region, Slovenia included, tend to recognize pimping and mediation in prostitution as criminal offences, while none of the countries regulates demand, an issue that has recently been debated in Croatia.

Equal opportunity policies in the region still do not address the gender, economic and class inequalities that often lead to prostitution and trafficking. Social destigmatization of prostitution is also a questionable trend, and media analysis suggests that portrayals of women involved in prostitution and trafficking are still rife with stereotypes (Pajnik, 2010). Dwindling social welfare programs, cuts in education and health services, the rise of poverty and its feminization, along with rising unemployment among women, income disparities as well as paternalist family and household structure (Fodor, 2002) have turned prostitution into one of those few occupations that provide a living for a growing number of women across the region. Studies (Corrin, 2005) have reported that women who are most vulnerable to poverty (divorced women with children, single mothers and women from mino- 
DRUŠ. ISTRAŽ. ZAGREB GOD. 22 (2013), BR. 2 STR. $257-276$

PAJNIK, M.: RECONCILING... rity groups) are also most vulnerable to trafficking that has grown in the CEE / SEE region in the post 1989 period. The Balkans have habitually been described as the crossroads between East and West in the sex trade. Political and economic liberalization together with wars and militarism in the SEE region (i.e. Bosnia, Kosovo, Serbia, Macedonia) have solidified such an image that made these countries increasingly source and transit countries for trafficking (Kligman \& Limoncelli, 2005, p. 125, 127).

The globalized sex industry expanded rapidly after 1989, as did the related areas of pornography and strip/sex clubs and shops (True, 2003; Kligman \& Limoncelli, 2005). In her analysis of the changed gender relations in the Czech context, True (2003, p. 27) argues that the marketization and commodification of sex produced puzzling effects, with women appearing as both agents and victims of the transition process. While, on the one hand, it can be argued that the liberalization of CEE countries contributed to the decriminalization and destigmatization of prostitution, given that prostitution ceased to be considered a crime; on the other, it did not have concrete positive effects on women in prostitution. We have witnessed the proliferation of sexual images that are also facilitated by new information and communication technologies, where the "pornographisation of sexuality" (Šribar, 2007) is a growing trend. Market liberalization and European integration processes further created specific sexual desires and practices, with Eastern-European women being exoticized with the purpose of stimulating growth in the sex industry.

\section{PROSTITUTION IN PRACTICE, AS GLEANED FROM STORYTELLING}

Here we present findings from the research study conducted in Slovenia which examined prostitution from the perspectives of gender, migration, work, organization and demand. We were interested in the views and experiences of people working in prostitution and their clients. To be able to encompass the complexity of relations, we also sought to hear the opinions of the prostitution managers (pimps), policy makers and NGO activists who shape the representation of prostitution through public debate and policy making.

Similar as in other CEE / SEE countries, post-socialism in Slovenia brought a rise in and vast diffusion of the sex industry. Research (Pajnik, 2008) confirmed the existence of various forms of prostitution, the most spread being the hidden "apartment prostitution", followed by escort, hotel and bar prostitution related to prostitution for drugs. Legal stipulation valid until 2001 that treated prostitution as an offence was abolished and prostitution decriminalized. Despite legal barriers, 
DRUŠ. ISTRAŽ. ZAGREB GOD. 22 (2013), BR. 2, STR. $257-276$

PAJNIK, M.: RECONCILING.. procurement is a diffused way of prostitution organization while self-organizing is also on the rise and is viewed as a way to avoid violence and income loss. Estimates by the police are that the majority who work in prostitution are native-born while there is a clear niche in the market for migrant prostitution. Forced prostitution is reported to be on the rise by NGOs, and Slovenia was recognized (Zavratnik Zimic, Kavčič, Pajnik, \& Lesjak-Tušek, 2003) as a transit, source and also as a destination country for trafficking. Recent research (Pajnik et al., 2012) has confirmed a visible reallocation of prostitution in the online environment. The web is largely used by the organizers to explore opportunities for their business while voices of women and men in prostitution are hardly visible online.

Field work was conducted in Slovenia in 2006 and 2007, and we interviewed 6 individuals working in prostitution, 6 clients, 2 managers/procurers, one administrator of an e-forum, and 6 experts - NGO members and officials dealing with the issues of prostitution and/or human trafficking. We collected and analyzed data using the qualitative method of semi-structured interviews. The study comprises the analysis of narratives, theme-oriented interviews that were adapted to individual groups of respondents. Authors (Lieblich and Josselson, 1997), working with narrative interviews - these are especially appropriate in cases of researching marginalized groups remind us of the validity of smaller samples that provide different, but equally significant insight into a thematic if compared to quantitative representational samples. Although our data are not to be generalized but rather read in the context of the research - the intention was to provide insight into the different realities of prostitution and to address the puzzle of the voluntary and involuntary factors in prostitution / trafficking (Pajnik, 2008) - we nevertheless feel confident that the data we have obtained with the diversified sample meaningfully highlight the complex realities of the sexual industry that cannot be sufficiently explained within unilinear and dogmatic argumentation. ${ }^{1}$

Various methods were employed to establish contacts with women in prostitution and with clients, i.e. through advertisements, websites and forums while the establishment of contacts through personal acquaintances and snow-ball method were most efficient.

The group of clients interviewed includes only men, who according to some estimates (O'Connell Davidson, 1998) account for the vast majority ( 95 percent) of sex service users. Since our study was limited in terms of scope and timeframe, we could not conduct interviews with men in prostitution or women, lesbians or couples who buy sex, although field expe- 
rience confirms that supply and demand are multifold. Similarly, organizers of prostitution from our sample are men, although several participants confirmed that women, too, are involved in the organization.

\section{On reasons for prostitution}

The women who participated in our research (aged 25 to 35), ${ }^{2}$ constitute a very heterogeneous group. Some are employed but work in prostitution because their livelihood depends on this additional income; others are students deriving from prostitution additional income that enables them to lead a more comfortable life. Some have secondary education, while one has a university degree; one woman is married; others live with partners or are single. The majority have been engaged in prostitution for less than five years, while for others, prostitution has been the only income for a longer time; some work independently, others provide shares of their earnings to organizers. Some work in "apartment prostitution", the most prevalent form in Slovenia, others are related to hotels and night-clubs, and it is frequent for most to commute to border regions, especially to Italy, but also Austria, Croatia and Hungary.

The majority of interviewees were convinced that money is the main reason behind prostitution, the money needed either for living expenses, or to support family members, or to pay for children's schooling, or to achieve financial independence from a partner. Some interviewees who work as prostitutes pointed out that they would not engage in prostitution if they had another option. This led us to the observation that women's desire or need to improve their economic situation should be interpreted within the wider context of living conditions and options. Similar is the suggestion of Limoncelli (2009), who pleas for a gendered political economy approach to prostitution and trafficking that recognizes social relations under global capitalism in their gender, ethnic, class etc. configurations.

The reason was my social circumstances. I had no job and was in debt. That's how it began. (Manja)

At that time I was twenty-one. And I did it for the extra income, I did it in addition to my studies, meaning writing, journalism. Indeed, I knew all the while that it was temporary. I knew that one day I'd use my brains to earn money. I somehow bet all on my body, but I knew that I was not the type of woman to do it all my life. And it was very simple to end with it. No traumas. I got an additional translation job by chance and it smoothly replaced that income. 
DRUŠ. ISTRAŽ. ZAGREB GOD. 22 (2013), BR. 2, STR. $257-276$

PAJNIK, M.: RECONCILING..
The earnings depend on what you offer and how long you work. I use this money to pay rent for the apartment which I share with other girls. Once a month I go shopping in Italy, I pay for exams occasionally, although I mainly get money for that from my parents, and I have enough money to get me through the month. I'm fine like this. And I also intend to complete my university studies and work in my profession. (Manuela)

Money is one of the frequently emphasized reasons for working in prostitution, although this should not be interpreted unequivocally. One of the respondents who works in prostitution pointed out its advantages in terms of earnings and time invested compared to other low-paid and physically strenuous jobs. At the same time, she said that she would definitely not work in prostitution if she had another option.

The money is the real reason. I wouldn't do this if I had a well paid job. If I had my degree and a well paid job, I wouldn't do this. This is a temporary job for me, I do it while I study, until I get a degree. It is transitory, until, as I said, I find a real job. If I had it, I'd never ... And I don't want it in the long run. I don't aim for it. (Ina)

Reflecting on his experience, a night club owner proposed a similar opinion.

Many of them find it hard to do it. But despite that, they then get those, say, hundred euros. It's probably hard to go with a client. If she has a drink, it's a bit easier. Some don't have problems, most of them don't. But, you know what, you don't have a real choice. (Vinko)

While some said that working in prostitution for them was a quick fix, until they found a better job, for others it was a way to earn money for everyday living expenses. Some thought that a certain number of women opted for prostitution to be able to afford "a comfortable life", meaning to obtain money for "goodies", as one respondent put it. This respondent also stressed that she gained sexual experience. The statements below are examples of the rationalization and legitimization of prostitution as sex work:

I thought it was fun. Of all of us who were there, I was the least burdened. ... I found it really funny and I'm lucky that I'm not traumatized over it. On the contrary. I accumulated quite a lot there. Given that I met, I don't know how many, probably more than five hundred men. So you somehow get to learn what the manuals cannot tell you.... I was probably different in this respect from other girls; probably, I can't be sure about it. I intuitively explained to 
DRUŠ. ISTRAŽ. ZAGREB GOD. 22 (2013), BR. 2 STR. $257-276$

PAJNIK, M.: RECONCILING... myself that what I was doing was not problematic. I never regretted it, never. I was sure of myself, sure that I did it well. In this way you gain some self-confidence and I only benefited from it. (Sara)

I thought it was fun, I really thought it was fun. When I started I was 21, that is the age when you still can sell yourself, once you're over 25 your chances are slim. I played various roles, as a transvestite, as a man I offered both, so that I could have more clients and I could play both roles, actively and passively ... I found it fun, I was also taken as a woman, as a female prostitute, and the money was only extra. (Julija)

Prostitution is, of course, a highly gendered phenomenon. Some of our respondents compared gender in prostitution with the historical and culturally determined practices of women's subordination. In this context the motive for working in the sex industry appears to be determined by social relations that produce social and economic differences. They further explained prostitution by using the argument of genderbased consumer practices, the burden of family work, unequal status of women on the labour market, and last but not least, the unequal payment system and large social differences.

The main reason for prostitution is the abuse of women's placement in a certain context of gender relations. There should be greater emphasis on gender equality, in the sense of greater employment of women in certain sectors. More emphasis should be placed on equal opportunities, labour division within the family and in raising children ... Women should have more opportunities for self-realization, their status should be regulated, for example, the status of single mothers, they should be given rights, and domestic work should be promoted as employment. (NGO worker)

Women want to be financially independent. They don't want it [prostitution] as a profession. Women earn less than men, although they have the same education and jobs. I think that many are dependent on their partners, boyfriends or husbands, but they don't want that; they want to be independent and this is a way to earn more. (Ina)

\section{Voluntary vs. forced prostitution}

Our analyses encompassed the relation between the voluntary and involuntary factors within prostitution. The respondents sometimes made a distinction between prostitution and human trafficking, and sometimes tried to view them together, but they also invariably tried to establish what possible con- 
DRUŠ. ISTRAŽ. ZAGREB GOD. 22 (2013), BR. 2, STR. $257-276$

PAJNIK, M.: RECONCILING.. sequences would arise from considering the two phenomena separately. It seems that the more common approach is to establish a clear dividing line, although some answers suggest attempts at recognizing practices that cross this line.

In the view of our respondents, prostitution is an activity for which a woman opts of her own will, although in so doing they do not brush aside the significance of "free choice", for example, the possibility that in this case free choice is determined by a lack of other opportunities. Some expressed a belief that only a small proportion of women choose prostitution for reasons other than economic, although the opinions varied. One respondent put the percentage of voluntary prostitution in Slovenia at around 30 percent. Others estimated that only a very small percentage of women work in prostitution for reasons other than economic. Prostitution was linked to poor social or economic circumstances, while other reasons that are believed to restrict women's choices were alcohol abuse, violence in the family and low levels of education.

An opposite attitude to prostitution could also be identified. Some respondents described it as "fun and good earnings". Regardless of this, women in prostitution are frequently exposed to pressure (exerted by providers or clients), which is why many see prostitution as a temporary job; they are active for some time, then retreat, and perhaps return to it after a time.

The differences between voluntary and forced prostitution are blurred. What does it mean for someone to be a prostitute and to say: it is my decision. What were her motives? Insufficient attention is devoted to this. Our understanding runs along the lines, well, she is a prostitute, that's her decision, that's what she wanted, but in reality we never give a thought to the underlying reasons, her economic situation, family environment. Too often it is assumed that it was their free decision. This generates the attitude to the effect, if you want to pull out of prostitution, do it and find some other job. (NGO worker)

The majority of prostitutes we interviewed drew a clear dividing line between forced and voluntary prostitution. Force is mainly associated with physical force or violence.

In my case, it is voluntary, and I'm glad that I can work like this, that it is not illegal and there is no coercion. No force, nobody telling me I must do it. I do it voluntarily and I'm glad that I can work like this, two or three days a week, which is not too much. (Ina) 
DRUŠ. ISTRAŽ. ZAGREB GOD. 22 (2013), BR. 2 STR. $257-276$

PAJNIK, M.: RECONCILING...
This respondent understands coercion as not necessarily coming from a pimp. Her answer alerts us to the obscuring of borders between forced and voluntary prostitution: she explains that prostitution is her own choice, but that she is willing to work as a prostitute two days a week at the most. Another indicator that points to the intertwining of coercion and voluntary factors is the frequently asserted fact that they would not be in prostitution had they had an opportunity to find another job.

\section{THE VIOLENCE PARADIGM}

The stories of protagonists in prostitution in Slovenia reveal that prostitution is a diffuse activity and indicate the complexity of relationships within the global sex industry, but also demonstrate the need to transcend the abolitionism / sex work dualism. Below, I analyze the two paradigms of prostitution that have emerged from contemporary debates. In so doing, I draw attention to the inadequacy of each of these approaches and argue that complex relationships in prostitution as presented above need to be addressed within the area where the two predominant views intersect. The two paradigms are first discussed based on a critical examination of the literature, while the concluding chapter argues for a reconciliatory approach.

According to abolitionists, prostitutes are the victims of violence, patriarchal practices, and dominance-subordination relationships, and the plea usually amounts to demand for the abolition of the sex industry and pornography, and for the criminalization of human trafficking. Theorists argue that clients and pimps exploit prostitutes, sustaining in this way the sex industry, gender inequality, increasing violence, and reinforcing prostitution as a patriarchal institution (Barry, 1985; Dworkin, 1987). Today, the texts that examine prostitution in connection with violence and traumatic personal experience frequently assume abolitionist arguments dating from the 1960s to the 80s (Jeffreys, 2006; Farley, 2004; Aghatise, 2004). Within this paradigm, the assumptions underlying various groups' manifestos and studies ${ }^{3}$ are as follows: 1 ) prostitution is an extreme example of male domination over and exploitation of women; 2) violence is invariably part of prostitution, or in other words, prostitution is a form of violence; 3 ) women in prostitution are victims and sex slaves; 4 ) de-criminalization or legalization would normalize prostitution and vindicate exploitation.

Critics of this approach emphasize that an excessive focus on women as victims of male domination isolates prostitution from other cases of inequality, such as unequal position on the labour market. It is also argued that this approach pre- 
DRUŠ. ISTRAŽ. ZAGREB GOD. 22 (2013), BR. 2, STR. 257-276

PAJNIK, M.: RECONCILING.. vents women from experiencing, experimenting and naming their own sexuality, and thus denies a proactive role of women in prostitution and in society as a whole. Those advocating for the rights of women in prostitution emphasize that the victim-rescuer perspective lacks individual voices, including the voices of those who are not necessarily victims. The abolitionist approach has also been criticized because its goal is the elimination of prostitution, so it contradicts efforts towards the improvement of prostitutes' working conditions and their social security. The abolitionists, on the other hand, see the solution to the issue of inadequate working conditions in the elimination of prostitution rather than in "making prostitution less unpleasant" (Allwood, 2004, p. 149).

As regards policies, the abolition mechanisms frequently place emphasis on rescue and rehabilitation. They advance the type of legislative provisions that support more severe measures against prostitution. One such example is the Swedish law on the purchase of sex services, passed in 1999, which criminalizes the consumption of prostitution. The law incriminates the buyers of sex, penalizing such offences with up to six months in prison and obligatory inclusion in a rehabilitation program. A new feature of Swedish policy is that it focuses on clients rather than on prostitutes. Despite this generally important shift, the fact that the new approach involved a repressive rather than a preventive measure has provoked ambivalent responses.

Advocates for abolition across Europe received the law with approval, seeing it as a step towards the termination of prostitution. On the other hand, the critics are becoming increasingly vocal, drawing attention to the fact that prostitution will not vanish because of this law but will only be relocated and will adopt new organizational forms (Kulick, 2003, pp. 210-211). Although the law is concerned with the protection of prostitutes and gender equality, the International Prostitutes Collective 4 has drawn attention to the problem involved in an approach that criminalizes clients - it neglects the position of persons involved in prostitution. The warning has come in the wake of the conclusion that the position of prostitutes has only deteriorated with the criminalization of clients. Early evaluations have shown that street prostitution, which fell somewhat in 1999, rose again after 2002, reaching the pre-law level. Other consequences of this law include an increase in online advertisements for prostitution, increased migration of women to other countries and relocation of prostitution to more discreet areas away from the prying eyes of the police. It has also been assessed that the number of migrants involved in prostitution in Sweden has increased and many now work in more difficult conditions. According to the police sources, cri- 
DRUŠ. ISTRAŽ. ZAGREB GOD. 22 (2013), BR. 2 STR. $257-276$

PAJNIK, M.: RECONCILING... minalization has not reduced the number of criminal offenses related to trafficking, and NGOs and the police now receive less information from clients than in the past (Gould, 2002; Kulick, 2003).

On the other hand, the pressure on prostitutes has increased because they are now compelled to appear as witnesses in court proceedings against their clients. Social workers have concluded that lower prices compel women to take more clients, and more different clients, which makes them more vulnerable (Kulick, 2003, p. 204, 210). This said, the necessity of paying close attention to violence in prostitution with all due responsibility should not be overlooked. However, it should also be stressed that such policies might have the effect of marginalization of persons in prostitution and not of termination of violence.

\section{THE SEX WORK PARADIGM}

The debates that approached prostitution as sex work intensified during the 1980s, which was the period when the first forms of self-organization began to take shape. These debates drew primarily on the arguments by early liberal feminism and later Marxist feminism, and were framed as an antipode to interpretations of prostitution as sex slavery. Sex work began to be established through arguments that the sale of sex services is a form of livelihood. The term "service" replaced the once common "favour", and commercial service discourse replaced the image of prostitutes' "servitude". This was the period when sex workers began to formulate their demands for the recognition of sex work as a profession and to struggle for rights arising from labour laws, such as wages and social protection. Sex workers, advocates for the rights of women and men in prostitution, some trends within feminism and some trade unions thus strive for the concretization of rights, the elimination of victimization and social exclusion, while emphasizing that sex work is not the sale of the body but "the sale of a sex service", even if it is intimately related to the body (Alexander, 1998; Nagle, 1997; Doezema, 2000; Kuo, 2002).

The need to legitimize prostitution as sex work is also emphasized by those interpreting prostitution as active sexuality. From this perspective, prostitution is a practice that subverts cultural patterns and limited interpretations of sexuality; it introduces initiative into sexuality, gives a feeling of control over one's own body and empowers women to defy exploitation (O'Neill, 2001). As part of advocacy for sex work, prostitution is even seen as an emancipatory or empowerment practice (Blume, 2006). Prostitutes thus become active agents who actively enter into unequal social relations and subvert sexual norms, while determining the conditions of sex transactions and payment terms. 
DRUŠ. ISTRAŽ. ZAGREB GOD. 22 (2013), BR. 2, STR. 257-276

PAJNIK, M.: RECONCILING...
Over the past years, sex worker organizations across the world have issued several manifestos, for example the Sex Workers in Europe Manifesto, published in 2005, ${ }^{5}$ which draws attention to discrimination against sex workers. Its appeals include the following: 1) the right to non-discrimination, and the demand that anti-discrimination legislation should stipulate the protection of sex workers; 2) the right to the body, the recognition of sex work as consensual sex, whereby the manifesto distinguishes sex work from non-sex work, i.e., sexual violence or slavery; 3 ) the right to be heard and participate in public debates and policy-making; 4) the right to associate and gather, and 5) the right to mobility and presence in public spaces regardless of borders.

The manifesto rejects the abolitionist equation of sex work with violence, which is seen as victimization strategy that denies autonomy and differences. It defines sex work as a commercial activity and demands an end to legislation that incriminates and stigmatizes sex work; it demands a broader social and media decriminalization and destigmatization of sex workers. The manifesto recognizes that coercion, abuse and exploitation are present within the sex industry, as they are within any other area of work, but they are not the defining traits of sex workers or the sex industry. The signatories also demand the regulation of working conditions and social and health protection for sex workers. ${ }^{6}$

In the Netherlands the legitimization of sex work began in 2000, when the exchange of sex services for money was legalized as a form of work. The changes in the Dutch penal code legalized voluntary prostitution and its organization and increased the penalties for the exploitation of involuntary prostitution. The idea was to provoke social legitimization of prostitution and the recognition of prostitution as sex work by way of regulation, which was expected to improve the living and working conditions of individuals in prostitution (Outshoorn, 2004, p. 168).

During the years immediately following adoption of the new legislation, it was primarily the advantages of legalization that were emphasized. Recently, criticism of such regulation can also be heard. It is said that the compulsory ID card attaches a stigma to a sex worker and interferes with her intimate sphere. It is a lasting stigma that reduces the chance that a sex worker will ever opt for another type of work, or even precludes their chances of finding another job. It is assumed that unregistered prostitution will increase because not all want to pay taxes, and migrants will be particularly affected (Outshoorn, 2004, pp. 172-173). The two-track policy on prostitution means that EU citizens are issued licenses to work as sex workers, while control over migrants is greater. Greater supervision over brothels leads to brothels refusing to employ migrants, so women 
DRUŠ. ISTRAŽ. ZAGREB GOD. 22 (2013), BR. 2 STR. $257-276$

PAJNIK, M.: RECONCILING... without papers are pushed into an even more precarious situation (Freedman, 2003, p. 133).

Control also stigmatizes sex workers by registering them as if they were in the possession of a particular brothel (Visser, 2004, p. 46). In this light, the "Dutch tolerance" appears to be exclusively tied to the establishment of law and order. This is also confirmed by the fact that street prostitution has not been entirely decriminalized, that it is segregated and that this is explained by the necessity of guaranteeing the safety of residents. The official policy of tolerance is constituted on pragmatic principles and indifference (Van Doorninck, 2002).

All this provokes criticism of legalization and raises the question of whether it is truly the rights of prostitutes that are prioritized, or if what is involved has become a defensive policy of restricting their work. Legalization also raises the question of self-image and personal identification. Many individuals in prostitution do not self-identify as prostitutes, nor do they want to identify with sex workers. In fact, legalization does not interfere with the traditionally unequal relations between the brothel owners and individuals in prostitution, so critics argue that legalization should devote more attention to labour relations.

\section{AN ATTEMPT AT RECONCEPTUALIZATION}

Some hold that violence is inherent to prostitution, while others emphasize that prostitution is a legitimate work that involves a legitimate choice. The sex work paradigm undoubtedly contributes to the improvement of the situation of certain sex workers. It problematizes the unequal position of prostitution compared to other types of work and brings to the public's attention hidden types of prostitution such as samesex and transgender prostitution. At the same time, it seems that neither of these approaches offers a sufficient reflection on labour relations, social inequality and gender discrimination, the dimension pointed out by our interviewees. This raises the questions of the relation of prostitution to human trafficking, of exploitation that is present in both areas, and of personal choice, that is, to what extent involvement in prostitution or a decision to migrate for prostitution is a personal decision. Also, none of these standpoints challenges the implications of the doctrine of decision-making (or its absence), or questions how much room it leaves (or does not leave) for the thematization of circumstances explaining these "choices", that is, life experience and economic status. As narrations above have shown, these factors strongly determine what it means to work as a prostitute in each individual case. Given these dilemmas, which have been confirmed by our empirical findings, it seems reasonable to study sex work from a view- 
DRUŠ. ISTRAŽ. ZAGREB GOD. 22 (2013), BR. 2, STR. 257-276

PAJNIK, M.: RECONCILING.. point at which various perspectives intersect, meaning those that strive to achieve legitimacy for prostitution with a view to improving the position of sex workers while considering prostitution along with other forms of work.

The idiom of prostitution as work importantly challenges the stigmatization of sex work. However, the transformation of prostitution from invisible female (non)work into sex work, which was especially pronounced in the CEE / SEE region after the revolutions of 1989 , can also be critically viewed as a trend within contemporary neo-liberal labour society, which is based on principles of hyper-consumption. In the case of prostitution, this means the legitimization of capital accumulation within the fast-growing international sex industry. We can thus put forward the thesis that advocacy for sex work might reproduce those social relations that encourage the free flow of international financial transactions, while not saying much about human relationships.

The legitimization of sex work can in the short term improve the position of a certain minority of people in prostitution and the situation of their relatives. Those who are prepared to register and pay taxes can obtain health and social security, residence rights and inheritance rights. This is an important shift, although progressive social movements have been articulating the demand that these rights should be recognized regardless of status and outside the work category as well. The legitimization of sex work also brings with it the stigmatized label "prostitute"; none of our interviewees explicitly defined themselves as prostitutes or sex workers. The experience of Germany and the Netherlands shows that only some decide to register, since registration entails the loss of anonymity, which for many is a precondition for involvement in the sex industry.

The paradigm of sex work breaks up with a priori victimization, because it implies activity and action on the part of an individual who is not necessarily a victim. Nevertheless, the opposite conclusion is also valid: as confirmed by our interviews the sex work approach overlooks the link between prostitution and trafficking, for example, when force is involved in presumably voluntary prostitution and active decision-making in trafficking, as in the case of individuals who migrate knowing that they will be working in the sex industry, but who may nevertheless become victims of human trafficking. Therefore, although the paradigm of sex work may appear as a mechanism of recognition, it hardly intervenes in power relations and class, gender and ethnic inequalities.

When we speak about sex work, it is necessary to mention a discrepancy between the assumptions underlying legalization which consider prostitution a profession (implying permanency), and the aspirations of prostitutes. Many prostitutes 
DRUŠ. ISTRAŽ. ZAGREB GOD. 22 (2013), BR. 2, STR. $257-276$

PAJNIK, M.: RECONCILING...

\section{NOTES}

\section{REFERENCES}

assert that they are in prostitution only temporarily. Interviews conducted in Slovenia reveal that they considered prostitution a temporary solution and that they intended to engage in another activity (or had already done so). Some respondents emphasized that non-regulated prostitution suited them because they did not want to stay long in prostitution. Also, many think that the temporary character of prostitution is related to the wish to retreat from prostitution after several years for health and psychological reasons. Others thought that the temporariness of prostitution was related to youth more than in other professions (Pajnik, 2008, pp. 95-135). The narratives reveal that prostitution is not "solely" work, or that it is a specific kind of work strongly characterized by gender relations with all their historical legacy, in our case mostly related to post-socialism.

New theories of prostitution should be sought in the area where binary positionings (voluntary/forced prostitution, work/ non-work, legalization/prohibition) intersect. The legitimization of new policies pertaining to prostitution so far remains inside the established social paradigms. Innovation with the disruptive potential to introduce new perspectives requires action and the activation of reasoning that goes beyond the mechanisms that seem to reproduce the established social order.

1 Our subsequent research projects where we conducted more interviews with women and men in prostitution, gay prostitutes and migrants in prostitution confirm the findings discussed in this article (Pajnik et al., 2012).

2 According to opinions of clients and pimps, this is the most diffuse age group.

${ }^{3}$ See the Survivors of Prostitution and Trafficking Manifesto issued by CATW - Coalition Against Trafficking in Women in 2005 at http://action.web. $\mathrm{ca} /$ home/catw/readingroom.shtml? $x=82636$ [Date of retrieval: 12 May 2012].

4 International Prostitutes Collective at http://www.allwomencount. net/EWC $\% 20$ Sex\%20Workers/SexWorkIndex.htm [Date of retrieval: 23 March 2012].

5 The manifesto was drawn up and signed by 120 sex workers from 26 countries at the European Conference on Sex Work, Human Rights, Labor and Migration (October 2005, Brussels).

6 Sex Workers in Europe Manifesto at http://www.sexworkeurope.org/ site/index.php?option $=$ com_content\&task $=$ view\&id $=24 \& I t e m i d=$ 54 [Date of retrieval: 15 April 2012].

Aghatise, E. (2004). Trafficking for prostitution in Italy. Violence against Women, 10(10), 1126-1155. doi:10.1177/1077801204268608

Agustín, L. (2005). Migrants in the mistress's house: Other voices in the "trafficking" debate. Social Politics, 12(1), 96-117. doi:10.1093/sp/jxi003 
DRUŠ. ISTRAŽ. ZAGREB GOD. 22 (2013), BR. 2, STR. 257-276

PAJNIK, M.: RECONCILING..
Alexander, P. (1998). Prostitution: Still a difficult issue for feminists. In F. Delacoste, \& P. Alexander (Eds.), Sex work: Writings by women in the sex industry (pp. 184-230). San Francisco: Cleis Press.

Allwood, G. (2004). Prostitution debates in France. Contemporary Politics, 10(2), 146-157. doi:10.1080/1356977042000278784

Barry, K. (1985). Female sexual slavery. New York: New York University Press.

Blume, J. (2006). Prostitution should be seen as empowering some women. In L. Gerdes (Ed.), Prostitution and sex trafficking (pp. 86-90). Detroit: Thomson Gale.

Corrin, C. (2005). Transitional road for traffic: Analysing trafficking in women from and through Central and Eastern Europe. Europe-Asia Studies, 57(4), 543-560. doi:10.1080/09668130500105118

Doezema, J. (2000). Loose women or lost women: The re-emergence of the myth of white slavery in contemporary discourses of trafficking in women. Gender Issues, 18(1), 23-50. doi:10.1007/s12147-999-0021-9 Dworkin, A. (1987). Intercourse. New York: Free Press.

Farley, M. (2004). 'Bad for the body, bad for the heart': Prostitution harms women even if legalized or decriminalized. Violence against Women, 10(10), 1087-1125. doi:10.1177/1077801204268607

Fodor, E. (2002). Gender and the experience of poverty in Eastern Europe and Russia after 1989. Communist and Post-Communist Studies, 35(4), 369-382. doi:10.1016/S0967-067X(02)00026-0

Freedman, J. (2003). Selling sex: Trafficking, prostitution and sex work amongst migrant women in Europe. In J. Freedman (Ed.), Gender and insecurity: Migrant women in Europe (pp. 119-137). Aldershot: Ashgate.

Gall, G. (2006). Sex worker union organising: An international study. Houndmills: Palgrave MacMillan. doi:10.1057/9780230502482

Gould, A. (2002). Sweden's law on prostitution: Feminism, drugs and the foreign threat. In S. Thorbek, \& B. Pattanaik (Eds.), Transnational prostitution: Changing patterns in a global context (pp. 201-215). London: Zed Books.

Hrženjak, M. (2008). Freiwillige vs. unfreiwillige Prostitution = Prostitution vs. Menschenhande. Politische Diskussionen Über Prostitution und Menschenhandel in Slowenien. In J. Nautz, \& B. Sauer (Eds.), Frauenhandel. Diskurse und Praktiken (pp. 109-122). Göttingen: V\&R Unipress.

Hughes, D. M. (2000). The "Natasha" trade: The transnational shadow market of trafficking in women. Journal of International Affairs, 53(2), 625-651.

Jeffreys, S. (2006). The traffic in women: Human rights violation or migration for work? In Migrant Women and Work (pp. 195-217). New Delhi: Sage.

Kanduč, Z. (1998). Prostitucija: kriminološke, viktimološke in kazenskopravne perspektive. (Prostitution: Criminological, victimological and legal perspectives). Anthropos, 30(1-3), 88-106. 
DRUŠ. ISTRAŽ. ZAGREB GOD. 22 (2013), BR. 2 STR. $257-276$

PAJNIK, M.: RECONCILING...
Kempadoo, K., Sanghera, J., \& Pattanaik, B. (Eds.) (2005). Trafficking and prostitution reconsidered: New perspectives on migration, sex work, and human rights. Boulder: Paradigm Publishers.

Kligman, G., \& Limoncelli, S. (2005). Trafficking women after socialism: To, through, and from Eastern Europe. Social Politics, 12(1), 180-140. doi:10.1093/sp/jxi006

Kobal, M., \& Bavcon, L. (1969). Prostitucija (Prostitution). In M. Kobal, L. Milčinski, K. Vodopivec, \& B. Uderman (Eds.), Socialna patologija (Social pathology). Ljubljana: Mladinska knjiga.

Kulick, D. (2003). Sex in the New Europe: The criminalization of clients and Swedish fear of penetration. Anthropological Theory, 3(2), 199-219. doi:10.1177/1463499603003002005

Kuo, L. (2002). Prostitution policy: Revolutionizing practice through a gendered perspective. New York: New York University Press.

Lieblich, A., \& Josselson, R. (Eds.) (1997). The narrative study of lives. Newbury Park, CA: Sage.

Limoncelli, S. A. (2009). The trouble with trafficking: Conceptualizing women's sexual labour and economic human rights. Women's Studies International Forum, 32(4), 261-269. doi:10.1016/j.wsif.2009. 05.002

Nagle, J. (Ed.) (1997). Whores and other feminists. New York: Routledge. Oberstar, J. (2003). Migracije, trgovina z ljudmi in zaščita žrtev (Migration, human trafficking and victim protection). Pravna praksa, 22(8), 23-32.

O'Connell Davidson, J. (1998). Prostitution, power and freedom. Cambridge: Polity Press.

O'Neill, M. (2001). Prostitution and feminism: Towards a politics of feeling. Cambridge: Polity Press.

Outshoorn, J. (2004). Pragmatism in the polder: Changing prostitution policy in the Netherlands. Journal of Contemporary European Studies, 12(2), 165-176. doi:10.1080/1460846042000250873

Pajnik, M. (2008). Prostitution and human trafficking: Gender, labour and migration aspects. Ljubljana: Mirovni inštitut.

Pajnik, M. (2010). Media framing of trafficking. International Feminist Journal of Politics, 12(1), 45-64. doi:10.1080/14616740903429114

Pajnik, M., Bajt, V., Šori, I., Kambouri, N., Sarri, M., Zavos, A., \& Renault, M. (2012). Controversies of prostitution and trafficking online: Thematic report. Ljubljana: Mirovni inštitut; Athens: Panteion University. Available at: http://www.mignetproject.eu/wp-content/uploads/2012/ 10/MIGNET_Deliverable_10_Thematic_Report_Sexualities.pdf.

Radulović, D. (1986). Prostitucija u Jugoslaviji (Prostitution in Yugoslavia). Beograd: Zavod za izdavačku delatnost Filip Višnjić.

Šribar, R. (2007). Pornografizacija spolnosti (Pornographization of sexuality). Medijska preža, 28, 45-46.

True, J. (2003). Gender, globalization, and postsocialism: The Czech Republic after communism. New York: Columbia University Press. 
DRUŠ. ISTRAŽ. ZAGREB GOD. 22 (2013), BR. 2, STR. $257-276$

PAJNIK, M.: RECONCILING...
Van Doorninck, M. (2002). A business like any other? Managing the sex industry in the Netherlands. In S. Thorbek, \& B. Pattanaik (Eds.), Transnational prostitution: Changing patterns in a global context (pp. 193-200). London: Zed Books.

Visser, J. (2004). Problems encountered so far in the Netherlands. In "Hidden stories": Male sex work in Northern Europe, a Report from the Stockholm Meeting May 23-24, 2004, 43-47, Amsterdam, European Network of Male Prostitution (ENMP).

Weitzer, R. (2006). Moral crusade against prostitution. Society, (March-April), 33-38. doi:10.1007/BF02687593

Zaviršek, D. (1993). Prostitucija - izziv za drugačno socialno delo (Prostitution - challenge for a different kind of social work). Revija za kriminalistiko in kriminologijo, 44(1), 3-10.

Zavratnik Zimic, S., Kavčič, U., Pajnik, M., \& Lesjak-Tušek, P. (2003). Where in the puzzle: Trafficking from, to and through Slovenia. Ljubljana: IOM.

Zavratnik Zimic, S., \& Pajnik, M. (2005). Trgovanje z ženskami: Perspektiva žrtve (Trafficking in women: A victim's perspective). Teorija in praksa, xlii (1), 113-135.

\section{Pomirenje paradigmi o prostituciji uz pomoć naracije}

Mojca PAJNIK

Fakultet društvenih znanosti, Ljubliana

Članak je usredotočen na kontroverzu seksualni rad / nasilje u teorijjkim i empirijskim raspravama o prostituciii, s naglaskom na Srednju / Jugoistočnu Europu i, posebno, Sloveniju. U članku se analiziraju studije i rasprave o prostituciji u regiij u (post)socijalističkom vremenu. Zatim se prelazi na razmatranje dvostrukog učinka liberalizacije prostitucije u razdoblju tranzicije: dok je, s jedne strane, prostitucija bila destigmatizirana, s druge je bila komercijalizirana, kako bi služila gospodarskim interesima globalizirane trgovine $\mathrm{i}$ industrije seksualnim uslugama. Razgovori sa sudionicima uključenima u prostituciju u Sloveniji pokazuju kako su ti procesi utjecali na uvjete njihova života i rada. Iskustva osoba koje se bave prostitucijom otkrivaju složenost nïhovih situacija, pokazujući da ne postoji jasna razlika između prostitucije i trgovine ljudima te da su u nju uključeni i elementi dobrovoljnosti i prisile. Evaluacijom argumenata paradigmi seksualnog rada i nasilja, u članku se predlaže proučavanje prostitucije izvan binarnosti, u njezinoj heterogenosti, odnosno tematiziranjem raznih njezinih aspekata i uzimajući u obzir stvarnost sudionika $u$ prostituciji.

Ključne riječi: prostitucija, seksualnost, seksualni rad, nasilje, naracija, Slovenija 